\title{
インプラント治療における下顎臼歯部から採取した 自家頓側皮質骨移植についての検討
}

\author{
澤 裕一郎*,**・滝本 明**。渡邊悟朗** \\ 真野晃寿**.下田正穂**.川野 大 $^{* *}$
}

\section{Evaluation of autogenous buccal bone grafts harvested from the mandibular molar region for dental implant treatment}

\author{
SAWA Yuichiro $*, * *$. TAKIMOTO Akira $* *$. WATANABE Goro ** \\ MANO Akitoshi $* *$. SHIMODA Masao ** . KAWANO Dai **
}

\begin{abstract}
Molar sites of the mandible can provide larger quantities of autogenous bone than other intraoral sites. We clinically investigated the bone harvest procedure from the mandibular molar region. The subjects were 21 patients (28 regions) who underwent veneer grafting, onlay grafting, sinus lifting, or combinations of these procedures. The fragments were harvested from cortical bone in the mandibular body, and their mean size was $14.6 \times 22.4$ (range of minor axis 10-25, range of major axis 10-40) $\mathrm{mm}$ on each side. The fragments were used in block or particulate form, and the platelet rich plasma was used to promote bone proliferation and avoid complications. As for the results of bone augmentation, we could obtain adequate bone volume for the placement of fixtures in all patients. The mean extent of augmentation was equivalent to 3.24 (range 1-8) teeth, and the mean number of implants placed was 2.81 (range 1-7) fixtures. Two cases of mental nerve paresthesia and 1 case of bone exposure occurred as postoperative complications. In addition, bone blocks cracked in 2 patients at the time of fixture placement. However, the outcome of all cases of implant treatment was uneventful. This preliminary modified technique for harvesting bone from the ramus was useful for bone augmentation in patients undergoing implant treatment.
\end{abstract}

Key words: autogenous bone graft（自家骨移植），alveolar bone augmentation（茵槽骨造成法)， cortical block bone harvesting（皮質ブロック骨採取），mandibular molar region（下顎臼㐘部），implant treatment（インプ ラント治療)

緒言

インプラント治療における骨移植による骨造成手術で は，必要な骨量や採骨部への侵襲などの理由より口腔内か ら採骨した自家骨を使用する機会が多い。おもな採骨部位 はオトガイ部および下顎枝部であるが，オトガイ部では採 骨量は十分であるが下顎前柬の知覚鈍麻感やオトガイ神経

*藤枝市立総合病院口腔インプラントセンター (主任：澤 裕一郎)

**藤枝市立総合病院菌科口腔外科 (主任：宮城島俊雄)

* Division of Oral Implant Center, Fujieda Municipal General Hospital (Chief: SAWA Yuichiro)

** Department of Oral and Maxillofacial Surgery and Dentistry, Fujieda Municipal General Hospital (Chief: MIYAGISHIMA Toshio)

受付日：2005年 3 月 22 日

採択日：2005 年 12 月 20 日
麻痺などを生じやすく 1,2$)$ ，下顎枝部では偶発症の発生は 少ないものの，量に制限がある。そこで下顎枝前縁部から の採骨範囲を下顎第 1 大臼菌部付近まで延長した術式を行 ったところ，採骨量が豊富なうえにオトガイ神経麻痺の発 生も少なく良好な結果であることをすでに報告した ${ }^{3)}$ 。今 回われわれは下顎臼柬部煩側皮質骨から採取したブロック 骨の単独使用による骨造成法についてさらに臨床的検討を 行ったので報告する.

\section{対象および方法}

\section{1) 対象}

2001 年 4 月から 2003 年 3 月までにインプラント体の埋 入を目的として，下顎臼柬部煩側皮質骨を用いた骨移植に よる骨造成術を行った 21 名を対象とした。症例の内訳は， 男性 5 名，女性 16 名，年齢は $17 \sim 71$ 歳（平均 $43.7 \pm$ 
表 1 症例の内訳

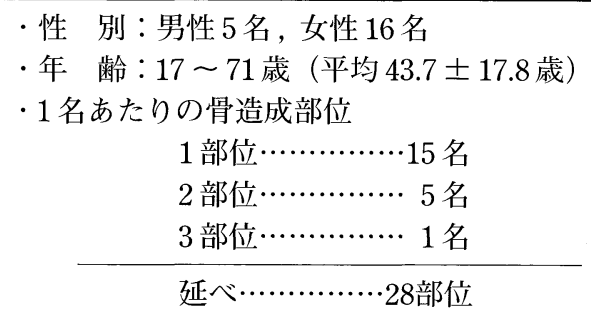

17.8 歳）であった. 1 名あたりの骨造成部位は， 1 部位 15 名, 2 部位 5 名, 3 部位 1 名であり, 延べ骨造成部位は 28 部位であった（表 1).28 部位の骨造成法の内訳は，上顎前 柬部ベニアグラフト 13 例, 上顎前茵から小田柬部ベニア グラフト 5 例，上頭臼柬部サイナスリフト 5 例，上顎臼柬 部アンレーグラフト 1 例, 上顎臼蒾部サイナスリフトおよ びアンレーグラフト 2 例, 下顎前蒾から小臼柬部べニアグ ラフト 2 例であった（表 2 ).

\section{2 ）採骨および骨移植手術方法}

骨移植予定部に茵槽頂切開を加え被移植骨面を露出させ 必要な骨移植範囲を確認した。次に下顎臼柬部煩側皮質骨 のブロック骨採取を行った。下顎枝前縁から下顎第 2 小臼 柬遠心煩側苗肉に至る切開を加え，オトガイ孔を避けて㐘 肉骨膜弁を剥離し下顎骨表面を下顎下縁付近まで露出させ た．事前に確認した必要移植骨量に応じて煩側皮質骨部の 骨切りを行った。採骨範囲の近遠心側にレシプロケーティ ングボーンソーにて垂直方向の骨切りを行い, 近遠心部の 垂直的骨切り線を結ぶように柬槽頂側の水平的骨切りをク ロスカットバーにて行った（写真 1-A）。 その後に茵槽頂側 の水平的骨切り線に骨ノミを挿入し, 下顎下縁方向の水平 的骨切りを行うことなく皮質骨のみを分割して採取した (写真 1-B，C). 止血後, 露出骨髄面はそのままの状態で閉 創した（写真 1-D）。採取したブロック状皮質骨を移植部に 適合するように調整し，残余の骨片は細片骨化した（写真 2-A，B). ベニアグラフトとアンレーグラフトについては 移植部にブロック骨をスクリューにて固定し，その周囲に あらかじめ用意した多血小板血漿 (platelet rich plasma 以 下 PRP と略す）と細片骨を混合し充填した（写真 3-A）. またサイナスリフトについては挙上した上方の洞粘膜側に ブロック骨を設置し，その下方に細片骨のみを充填した (写真 4-A). 骨移植手術から約 6 か月後に二次的に骨内人 ンプラントの埋入手術を行った（写真 3-B, 写真 4-B). イ ンプラント体埋入手術から約 6 か月経過後に二次手術を行 い上部構造を作製した（写真 5 ).

\section{3 ) 検討方法}

骨片採取については，片側あるいは両側の採取側，採取
表 2 延べ 28 部位の骨造成法の内訳

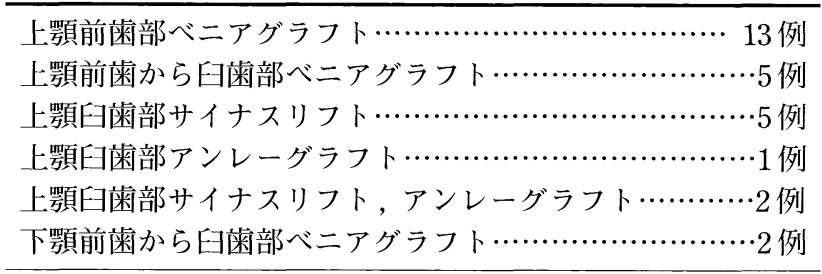

したブロック骨の大きさ，および採骨後の露出骨髄面への 下顎管の露出の有無について検討した．採取したブロック 骨は完全な立方形ではないため，大きさの計測は便宜的に 短径, 長径における最大径を四捨五入した $5.0 \mathrm{~mm}$ 間隔ご との大きさとした，骨造成範囲について，1 症例および 1 骨片あたりの骨造成範囲を欠損蒾数を用いて検討した。今 回は 2 例で両側から採骨したが，各骨片はそれぞれ別部位 の異なる骨造成法に用いており，両骨片を同一骨造成部位 に併せて使用した症例はなかった，術後合併症に関しては， 創部離開による移植骨の露出の有無と露出時の対応，術後 感染の有無, 術後オトガイ神経麻痺の発生および回復状態 について観察した．また，インプラント体埋入時の移植骨 片の癒合状態抏よびインプラント体埋入本数について検討 した。なお今回は同時に埋入された非骨造成部のインプラ ント体埋入本数は含まれていない.これらの調査結果から 下顎臼歯部煩側皮質骨採取による骨造成法の特徴について 検討した.

\section{結果}

全例においてあらかじめ予定された部位へ必要な本数の インプラント埋入が可能で，二次手術を経て上部構造も作 製された. 現在まで脱落したインプラント体はなく機能し ている。

\section{1) 採取骨片量}

骨片の採取側は片側のみが 19 例, 両側が 2 例で, 採取し た総骨片数は 23 片であった. 全 23 片の骨片の大きさは最 小 $10 \times 10 \mathrm{~mm}$ から最大 $25 \times 35 \mathrm{~mm}$ ，骨片の短径および長 径の平均值は $14.6 \times 22.4 \mathrm{~mm}$ であった（表 3 )。採骨後の 露出骨髄面に下顎管が露出した症例は 1 例のみであった.

\section{2 ）骨造成範囲}

1 症例あたりの骨造成範囲は 1 ～蒾で延べ 68 㐘, 平均 3.24 菌であった（表 4). 片側採取例，両側採取例を合わせ ると合計 23 片の骨片が採取され，1骨片あたりの骨造成範 囲は 1 ～ 6 茵で平均 2.96 㐘であった（表 3). 

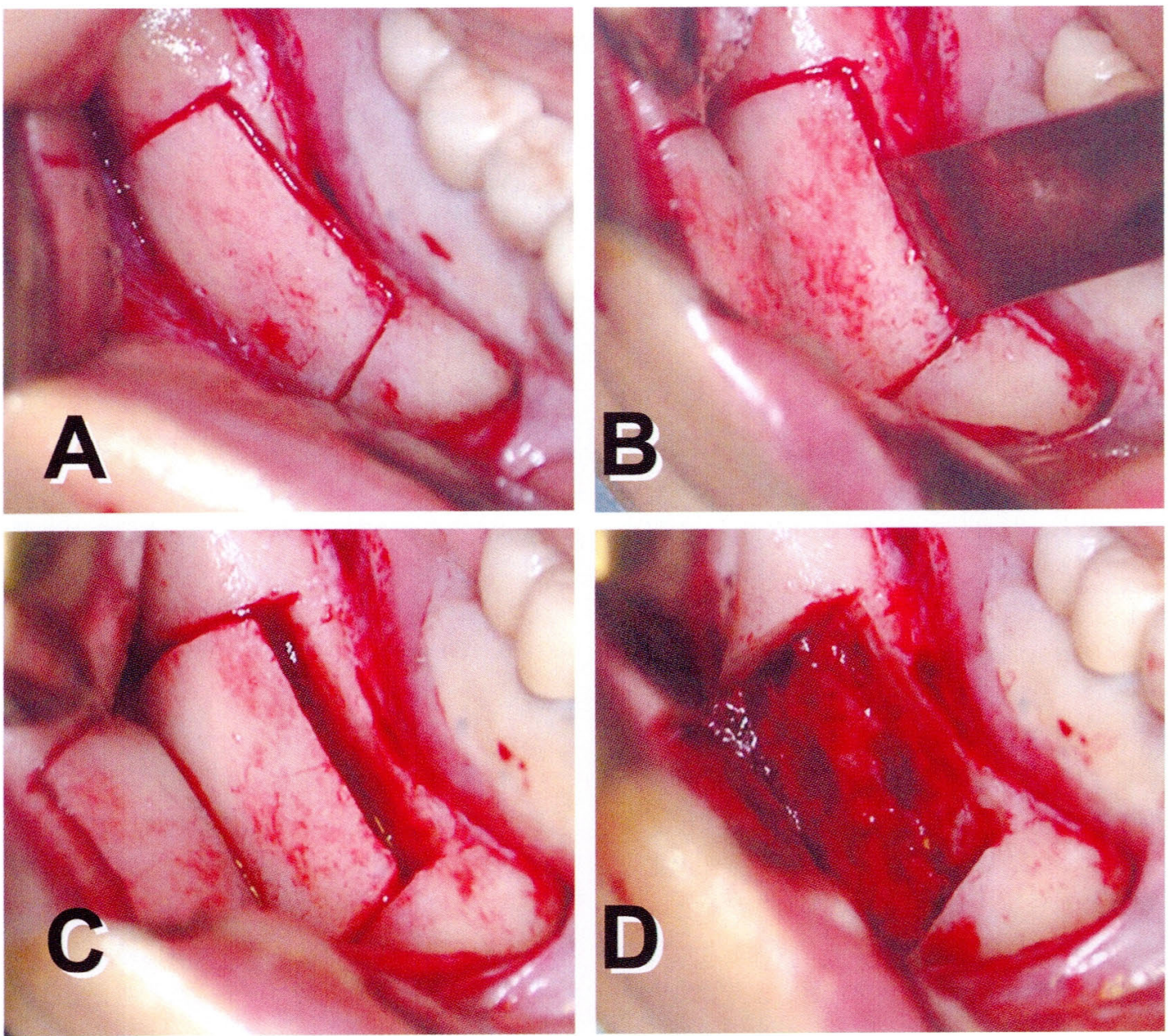

写真 1 右側下顕臼㐘部煩側皮質骨の採取法
A：骨切り時
C：骨片分割時
B：下縁方向の骨切りは行わずに骨ノミにて分割
D：採骨後の露出骨髄面
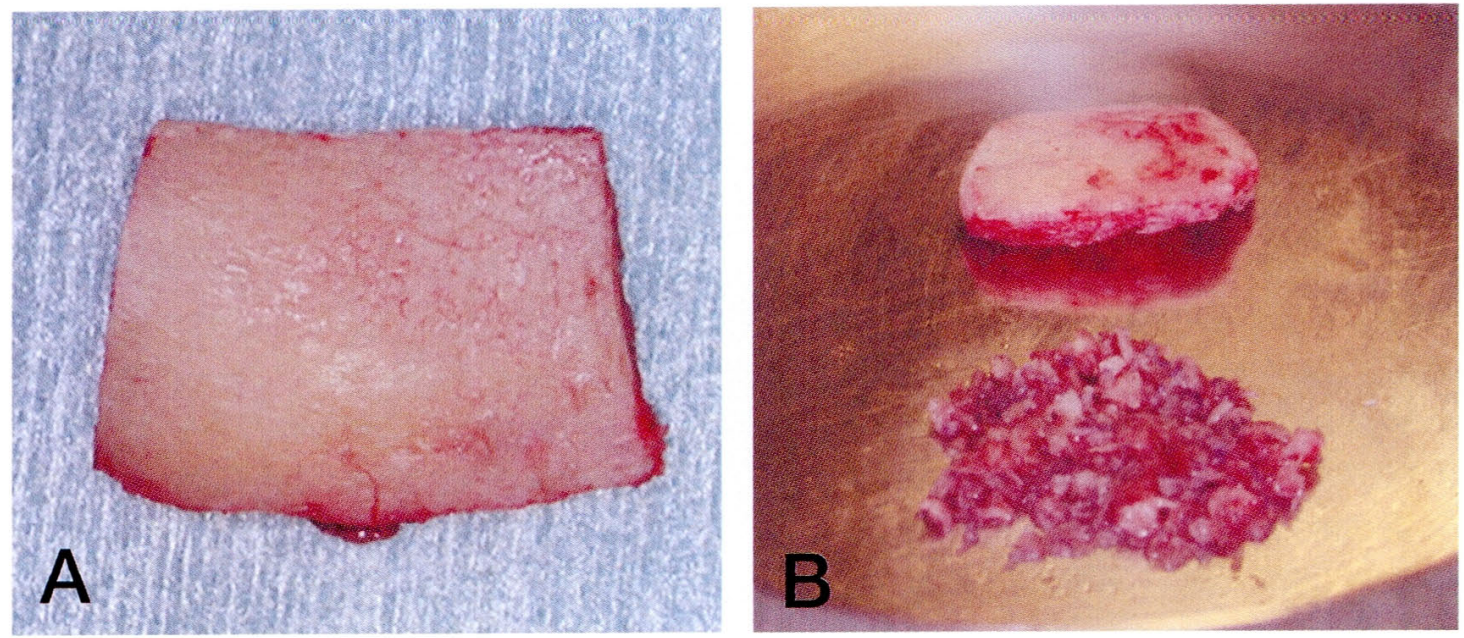

写真 2 採取した骨片と調整後の移植骨

A：採取した骨片Ｂ：ブロック肖と細片骨に調整 

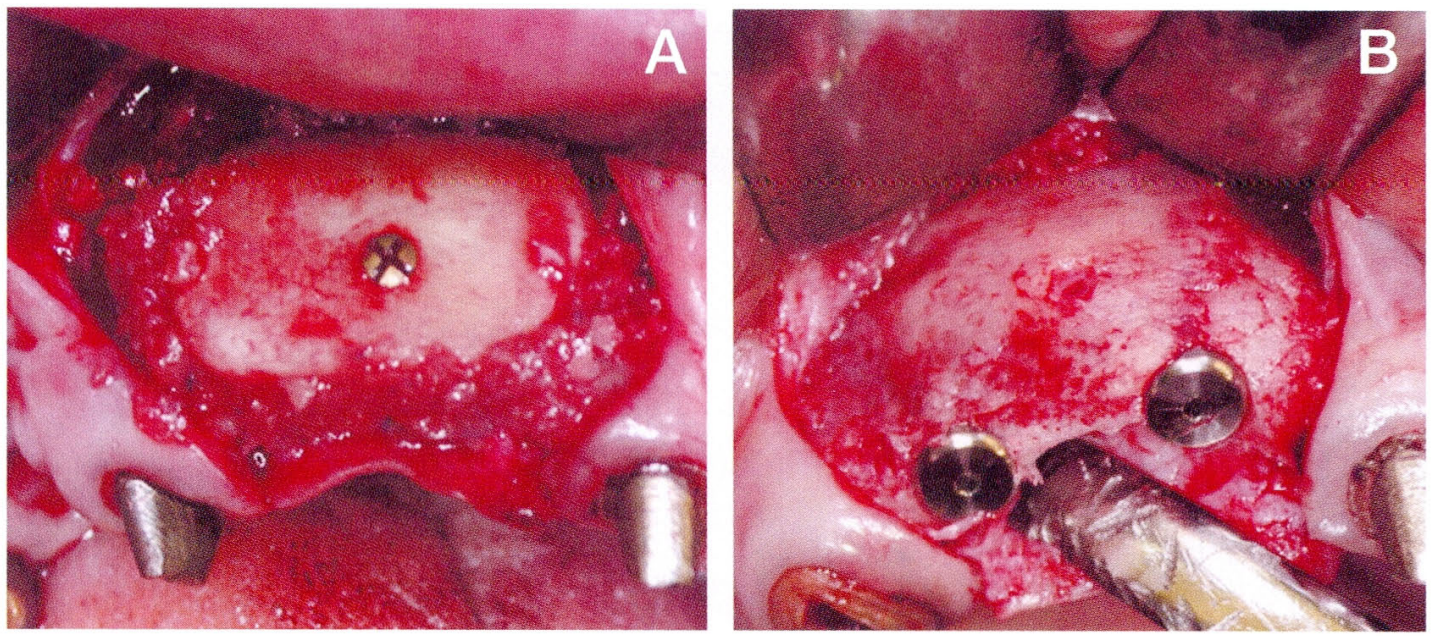

写真 3 右側上顎前蒾部ベニアグラフト症例

A ：ブロック骨をスクリューにて固定し，周囲に細片骨と PRP を充填した。 $\mathrm{B}$ ：インプラント埋入時
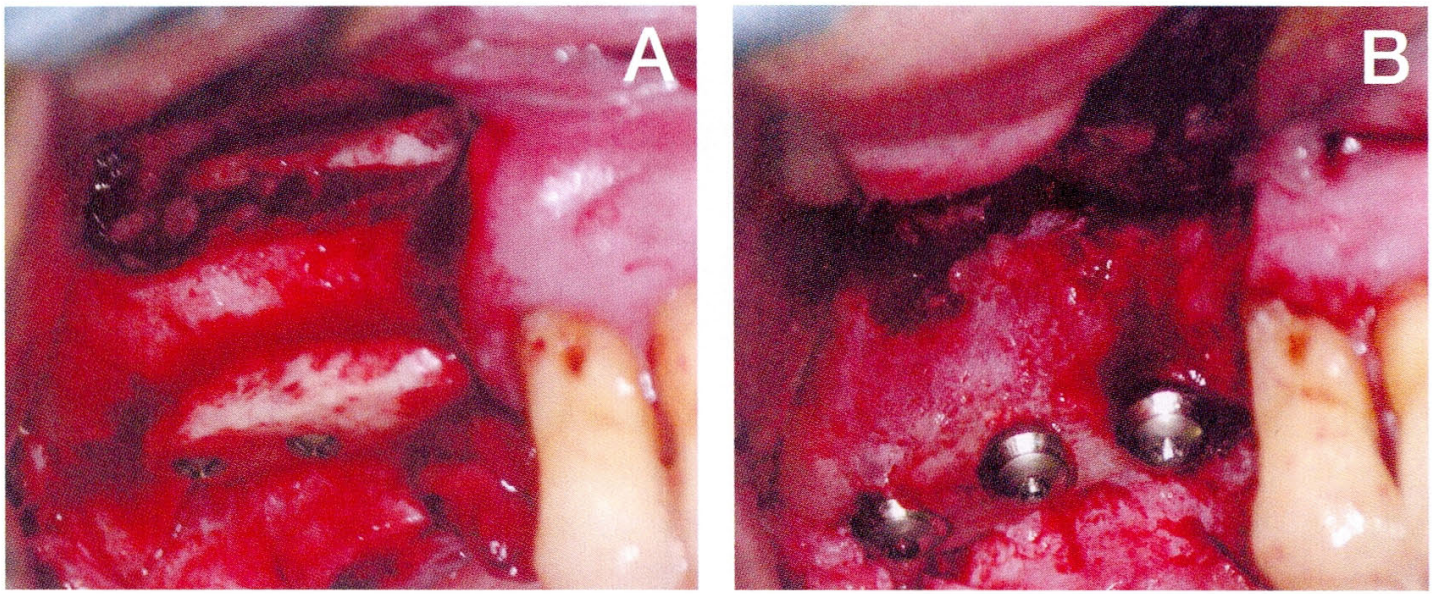

写真 4 右側上顎巨㐘部サイナスリフト, アンレーグラフト併用症例
A：サイナスリフトは，ブロック骨を開洞部の上方に抻人し，その下方に細片骨を充填した。アンレ
ーグラフトはブロック骨をスクリューにて固定し, 周囲に細片骨と PRPを充填した。
$\mathrm{B}$ ：インプラント埋入時

\section{3 ）術後合併症}

創部離開による移植骨の露出は上㖽前茵部にベニアグラ

フトを行った 1 例のみであったが, この症例においては明 らかな術後感染は生じなかったため, 抗菌薬の投与や頻回 の洗浄は行わなかった。術後オトガイ神経麻痺を生じたの は2 例で，そのうち 1 例は採骨中に下䫂管が露出した症例 であった．1例は術後 3 か月でオトガイ神経麻痺は完全に 消失したが，下顎管が露出した症例は術後約 2 年経過して もオトガイ神経麻痺の改善はみられず残存していた。これ らの骨片の大きさは $15 \times 20 \mathrm{~mm}$ および $15 \times 25 \mathrm{~mm}$ であ
つた.

\section{4 ) インプラント体埋入時の移植骨片の状態およ び埋入本数}

全例で骨片固定用スクリュー撤去時の移植骨片の癒合を 認めインプラント体埋入が可能であった。 1 症例あたりの インプラント体埋入本数は 1 ～ 7 本で平均 2.81 本であっ た（表 4). 1 骨片あたりの埋入本数は 1 ～ 6 本で平均 2.11 本であった (表 3$)$ ．このときの合併症は，インプラント体 埋入中に移植骨片と母床骨がわずかに分離した上顎前菌部 にベニアグラフトを行った症例と（写真 6-A），ブロック骨 
表 3 骨片の大きさと骨造成範囲拉よびインプラント体埋入本数

\begin{tabular}{|c|c|c|c|c|c|c|c|c|c|c|c|}
\hline \multirow{2}{*}{$\begin{array}{c}\text { 骨片の大きさ（症例数） } \\
\text { ミリメートル }\end{array}$} & \multicolumn{6}{|c|}{ 骨造成範囲（歯数） } & \multicolumn{5}{|c|}{ インプラント埋入本数 } \\
\hline & 1柬 & 2 柬 & 3 柬 & 4 柬 & 5 柬 & 6 柬 & 1本 & 2 本 & 3 本 & 4 本 & 6本 \\
\hline $10 \times 10$ & 1 & & & & & & 1 & & & & \\
\hline $10 \times 15$ & 3 & 2 & & & & & 3 & 2 & & & \\
\hline $10 \times 25(1)$ & & & & 1 & & & & 1 & & & \\
\hline $15 \times 20$ & & 2 & 5 & 2 & & & & 5 & 2 & 2 & \\
\hline $15 \times 25(2)$ & & & 1 & 1 & & & & 1 & 1 & & \\
\hline $15 \times 30$ & & & & 1 & & & & & & 1 & \\
\hline $20 \times 35(2)$ & & & 1 & & 1 & & & & 1 & 1 & \\
\hline $20 \times 40$ & & & 1 & & & & & & 1 & & \\
\hline $25 \times 35(1)$ & & & & & & 1 & & & & & 1 \\
\hline \multirow{2}{*}{ 合 計 (23) } & 4 & 4 & 8 & 5 & 1 & 1 & 4 & 9 & 5 & 4 & 1 \\
\hline & \multicolumn{6}{|c|}{ (平均 2.96 菌) } & \multicolumn{5}{|c|}{ (平均 2.11 本) } \\
\hline
\end{tabular}

(症例数)

表 4 1 症例あたりの骨造成範囲およびインプラント体埋入本数

\begin{tabular}{|c|c|c|c|c|c|c|c|c|}
\hline $\begin{array}{c}\text { 骨造成範囲 } \\
\text { (平均 : } 3.24 \text { 茵) }\end{array}$ & $\begin{array}{c}1 \text { 菊 } \\
(3)\end{array}$ & $\begin{array}{c}2 \text { 歯 } \\
(3)\end{array}$ & $\begin{array}{c}3 \text { 柬 } \\
(7)\end{array}$ & $\begin{array}{l}4 \text { 柬 } \\
(6)\end{array}$ & 5 菌 & $\begin{array}{l}6 \text { 柬 } \\
(1)\end{array}$ & 7 歯 & $\begin{array}{c}8 \text { 菊 } \\
(1)\end{array}$ \\
\hline $\begin{array}{c}\text { インプラント体埋入本数 } \\
\text { (平均 }: 2.81 \text { 本) }\end{array}$ & $\begin{array}{l}1 \text { 本 } \\
(3)\end{array}$ & $\begin{array}{c}2 \text { 本 } \\
(8)\end{array}$ & $\begin{array}{l}3 \text { 本 } \\
(5)\end{array}$ & $\begin{array}{l}4 \text { 本 } \\
(3)\end{array}$ & 5 本 & $\begin{array}{l}6 \text { 本 } \\
(1)\end{array}$ & $\begin{array}{l}7 \text { 本 } \\
(1)\end{array}$ & \\
\hline
\end{tabular}

部に亀裂が生じた上顎臼柬部にアンレーグラフトを行った 症例の合計 2 例であった（写真 6-B）。しかし幸い母床骨か ら完全に分離することはなくインプラント体埋入後の再固 定が可能であった。 二次手術時の所見では，すべてのイン プラント体は十分に固定されており，インプラント体埋入 時に分離や亀裂を生じた 2 例も含め移植骨片は母床骨と癒 合していた。

\section{考察}

インプラント治療は 2 回法から 1 回法へ，さらに即時荷 重へと手術回数の減少，治療期間の短縮など治療技術の向 上が著しい。その延長線上にある骨造成法も同様に低侵襲 で高い成功率が求められている，こうしたなかでインプラ ント治療に打ける骨移植による骨造成法も，口腔外から口 腔内の採骨へと移行してきた。もちろん，全顎的な骨造成 には多量の移植骨が必要であり口腔外から腸骨などを採骨 をせざるを得ない症例もあるが，患者の受ける負担を軽減 するためにもできるだけ口腔内からの採骨が望まれる。し かしオトガイ部では，前歯の知覚異常，オトガイ神経麻痺， 下顎前柬の柬根損傷など合併症の危険があり ${ }^{1,2)}$ ，下顎枝
前縁部では神経学的合併症は少ないが採骨量が少なく複数 蒾範囲の骨造成には適さない。そこで合併症の少ない下顎 枝前縁部から採骨範囲を下顎臼柬部まで拡大してより多い 骨量を採取することを目的として，骨造成手術を行った ${ }^{3)}$.

\section{1) 採骨について}

採骨した骨片の大きさの平均は $14.6 \times 22.4 \mathrm{~mm}$ で，最大 は $25 \times 35 \mathrm{~mm}$ であった. Misch ${ }^{4 ）}$ はオトガイ部からの採 骨では最大 $15 \times 50 \mathrm{~mm}$ と報告しており，本法では片側か らの採取でオトガイ部とほぼ同等の採骨量が得られた。両 側から採取可能であることを考えると，口腔内他部位と比 較しても採骨量は豊富であると思われた。本法は下顎骨体 部煩側皮質骨を採取するため，採取後に骨体部骨髄面が露 出することになり，骨髄性出血や下顎管の露出を生じる可 能性がある. 創部出血が問題となった症例はなかったが, 2 例 $(9.5 \%)$ にオトガイ神経麻痺を生じ，このうち 1 例は 採骨時に下顎管が露出した症例であった。解剖学的には下 顎且菊部における下䫟管の煩舌的走行位置は舌側 $1 / 3$ 以内 が多く ${ }^{5)}$, Bedrossian ら ${ }^{6)}$ は下顎枝前縁からの採骨手術に 扔いて，骨切り時に生じる骨髄からの出血を目安に皮質骨 骨切りを行えば下顎管を損傷することなく安全な骨切りが 可能であると述べていることから，煩側皮質骨のみの慎重 

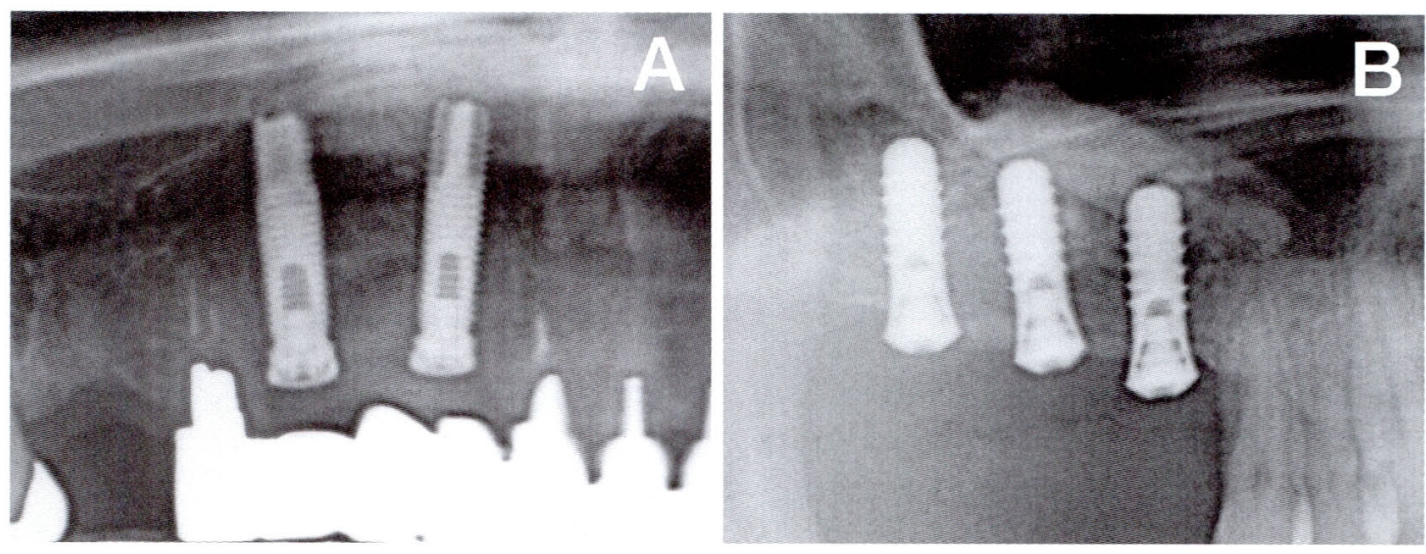

写真 5 インプラント体埋大後のパノラマ X 線写真

A：上顎前来部ベニアグラフト症例.

B ：上顎臼柬部サイナスリフト, アンレーグラフト症例。
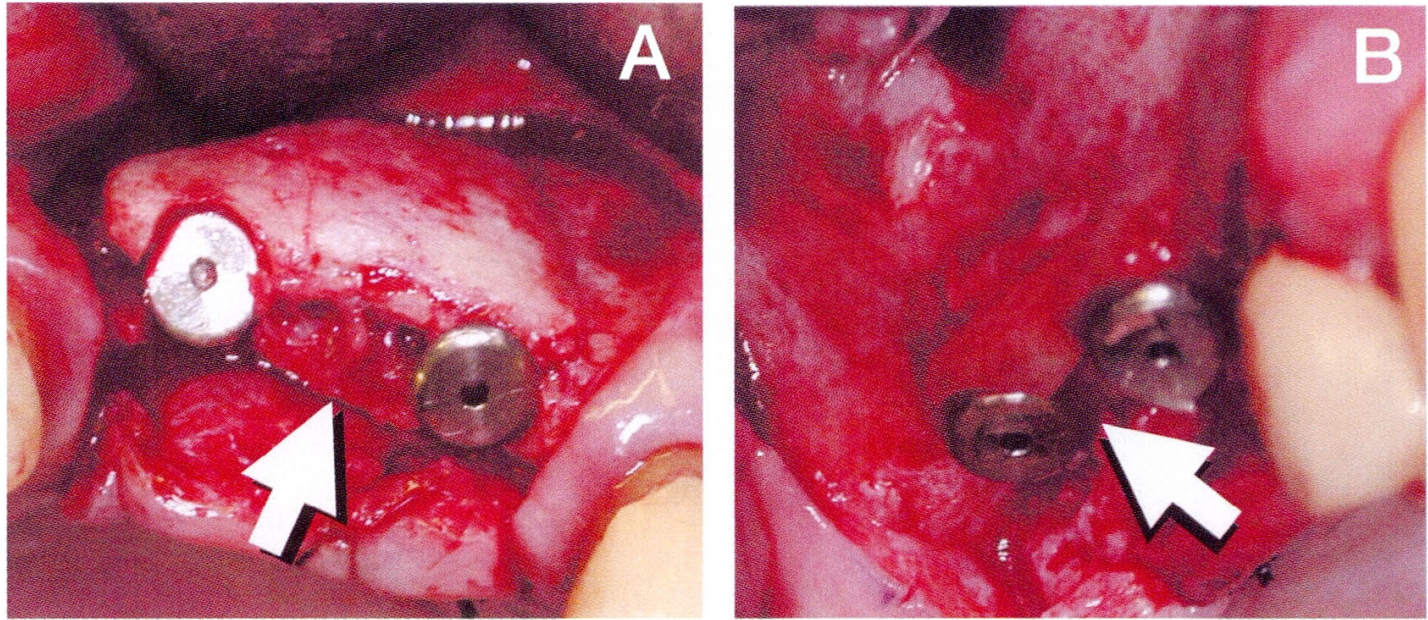

写真 6 インプラント体埋入時のブロック骨の分離と龟裂症例

$\mathrm{A}$ ：上買左側ベニアグラフト症例. 矢印は分離部を示す.

$\mathrm{B}$ ：上顎右側アンレーグラフト症例. 矢印は龟裂部を示す.

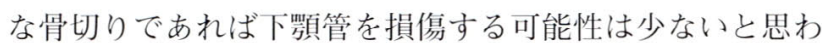
れる。しかし，今回の症例のように下顎管が露出するこよ もあり，CT 画像から下䫈管の位置を把握し慎重な骨切り を行うべきである。また，術中の筋鈎によるオトガイ神経 の伸展でもオトガイ神経麻痺を生じるため, 術中にオトガ イ孔を露出させないよう注意すべきである。

\section{2 ）骨造成術について}

全症例でブロック骨を中心とした骨造成法を行った。ブ ロック骨はチタンメッシュやメンブレンなどで被覆しなく ても骨造成部の形態維持が容易なことや，リモデリングが 緩徐なためインプラント埋入時までの吸収が少ないなど7), ベニアグラフトやアンレーグラフトなどの外向性の骨造成 に有利であった。骨造成範囲の平均は，1症例あたり 3.24
㐘，1骨片あたり 2.96 㐘と，およそ 3 秚程度であった。本 法による最大骨造成症例は 3 部位，8㐘範囲の骨造成部へ の 7 本のインプラント体埋入症例であり，従来のオトガイ 部や下靧忮部からの採骨による骨造成法を超えた複数部位 の多数柬範囲に及ぶ骨造成が可能であった。 また骨造成範 囲と骨片の大きさの関係は，1，2㐘範囲では $10 〜 15 \times 10$ 〜 20mm, 3 㐘以上では $10 \sim 25 \times 20 \sim 40 \mathrm{~mm}$ 程度の骨片 が使用されていた。この結果は骨造成法や容積によっても 異なるが採骨時のおよその目安になると考えている。しか し上顎全体に及ぶ垂直的吸収の著しい広範囲骨造成症例な どでは大量の移植骨が必要であり, 十分な骨造成法を行う ためにも口腔内からの採骨にとらわれずに採骨量の豊富な 腸骨や脛骨などを選択すべきであろう ${ }^{7,8)}$. その場合でも 
本法を併用することで腸骨の採骨量を減量させることがで きると思われる，とくに腸骨からのブロック骨採取は大き い侵襲を伴うため，ブロック骨を必要とする骨造成症例で は本法にて下顎骨臼歯部煩側皮質骨からブロック骨を採取 し，腸骨からは海綿骨骨髄のみを採取することで術後侵襲 を軽減できると思われた。

\section{3 ) 予後について}

骨造成手術後の予後不良因子としては，創部離開による 移植骨の露出や術後感染，移植骨の吸収，移植骨の母床骨 への癒合不全などがある ${ }^{9 \sim 11)}$. 今回は 1 例の移植骨露出 と 2 例の母床骨への癒合不全を認めた。本術式は創傷治癒 促進作用を有する PRP を併用した骨造成法である．PRP の創傷治癒促進効果による茵肉創部の早期閉鎖や移植骨と 母床骨の早期癒合を期待したが 12 ，13），PRP の使用効果に 関する客観的な臨床的評価は難しい. 最近では PRPには骨 形成促進効果がないことを指摘した報告もあり ${ }^{14,15)}, \mathrm{PRP}$ の影響については今後検討が必要である.

現在までの最長経過症例は骨移植後から 3 年経過症例で あるが，全症例で移植骨部の著しい吸収やインプラント体 の脱落を認めることなく経過している．今後は長期予後な ども含め，低侵襲で効果的な骨造成法について検討する予 定である。

\section{結語}

下顎曰柬部煩側皮質骨から採取した骨片による 21 名， 延べ 28 部位の骨造成を行い以下の結果が得られた.

1）1症例あたりの骨造成範囲は平均 $3.24(1 \sim 8)$ 菌 であった。

2 ）採骨した骨片の大きさは平均 $14.6 \times 22.4$ （短径： 10 ～25, 長径：10〜 40) $\mathrm{mm}$ であった.

$3 ） 1$ 例 $(4.5 \%)$ に術後に移植骨の露出を認めた.

4 ）オトガイ神経麻痺の発生は 2 例 $(9.5 \%)$ であった.

$5 ）$ 全例にて移植骨は母床骨と癒合しインプラント埋入 が可能であった.

\section{引用 文 献}

1) Clavero, J. and Lundgren, S.: Ramus or chin grafts for maxillary sinus inlay and local onlay augmentation: comparison of donor site morbidity and complications. Clin Implnat Dent Relat Res 5: 154-160 2003.

2) Nkenke, E., Schultze, M.S., et al.: Morbidity of harvesting of chin grafts: A prospective study; Clin Oral Implants Res 12: 495-502 2001.

3）澤 裕一郎, 滝本 明, 他：インプラント治療のた めの下買臼柬部煩側皮質骨移植による骨造成法. 日 口腔インプラント誌 17: 357-361 2004.

4) Misch, C.M.: Comparison of intraoral donor sites for onlay grafting prior to implant placement. Int J Oral Maxillofac Implants 12: 767-776 1997.

5）上條雍彦：口腔解剖学 1. 第 2 版, アナトーム社, 東 京, 1993, 217-224 頁.

6) Bedrossian, E., Tawfilis, A., et al.: Veneer grafting: A technique for augmentation of the resorbed alveolar prior to implant placement. A clinical report: Int J Oral Maxillofac Implants 15: 853-858 2000.

7）澤 裕一郎，滝本 明，他：上靧洞底挙上術後早期 に打ける移植部骨吸収に関する検討。日口腔インプ ラント誌 18: 31-38 2005.

8）鍋島弘充, Grageda, E., 他：擷堤再建のための脛骨 からの骨採取法. 日口外誌 48: 435-438 2002.

9) Tolman, D.E.: Reconstractive procedures with endossoeus implants in grafted bone: a review of the literature. Int J Oral Maxillofac Implants 10: 275-294 1995.

10）榎本昭二，立川敬子：自家骨移植法との併用. 末次 恒夫，松本直之監修；歯科インプラント。第 1 版， 先端医療技術研究所, 東京, 2000, 174-181頁.

11）寺田麻理，松井義郎，他：自家骨移植後の経過に関 する臨床的研究. 日ロ腔インプラント誌 16: 415-422 2003.

12) Marx, R.E., Carlson, E.R., et al.: Oral and maxillofacial surgery. Platelet-rich plasma-Growth factor enhancement for bone grafts. Oral Surg Oral Med Oral Pathol Oral Radiol Endod 85: 638-646 1998.

13）澤 裕一郎，川野 大，他：自己血からの多血小板 血漿（PRP: Platelet rich plasma）を用いた上顎前茵 部自家骨移植の 1 例一インプラント治療における骨 移植への有用性一. 日口外誌 46: 372-374 2000.

14）高山直士，田島雅道，他：培養骨芽細胞の増殖に対 する血漿の阻害的作用について. 日口外誌 51: 67-76 2005.

15) Edgar, G.: Platelet-rich plasma and bone graft materials: A review and a standardized research protocol. Implant Dent 13: 301-309 2004. 